\title{
機械学習による西日本豪雨時の商用車の 迂回の検出および迂回原因の分析
}

\author{
川崎 洋輔 1 ・梅田 祥吾 2 ・桑原 雅夫 3 \\ 1正会員 東北大学助教 大学院情報科学研究科（†980-8579 仙台市青葉区荒巻字青葉 6-6-06） \\ E-mail: kawasaki-y@plan.civil.tohoku.ac.jp \\ 2正会員 東北大学研究員 大学院情報科学研究科（ \\ E-mail: umeda@plan.civil.tohoku.ac.jp \\ 3正会員 東北大学教授 大学院情報科学研究科（广980-8579 仙台市青葉区荒巻字青葉 6-6-06） \\ E-mail: kuwahara@plan.civil.tohoku.ac.jp
}

\begin{abstract}
本研究では, 機械学習により, 西日本豪雨時の被災による商用車の迂回を検出するとともに迁回の原因 を分析する。西日本豪雨では，広範な地域で豪雨による道路閉塞が発生した。道路閉塞時の迂回を把握す るセンサーにプローブデータがある. しかし, 迁回を把握するには, 道路管理者が平常時のプローブ車両 軌跡を学習した上で, 分析する必要があり, 多大な労力を要する. そこで, One-class support vector machine (OCSVM)を用いて，平常時のプローブ車両軌跡を学習し，効率的に迂回の候補を検出することを試 みた。四国を対象に分析した結果，被災路線の直近の迂回路が通行可能であっても，大きく迂回する車両 が確認された．その迁回の原因を分析した結果，交通障害の“リスク”が一因であることが示唆された。
\end{abstract}

Key Words : one class SVM, commercial probe vehicle, Western Japan heavy rain, detour route, traffic failure risk

\section{1. はじめに}

本研究では，機械学習により，西日本豪雨時の道路被 災による商用車の迂回を検出するとともに，迂回の原因 を分析する. 2018 年の西日本豪雨では，広範な地域で 集中豪雨による道路閉塞が発生した。甚大な被災が発生 しており，復旧には時間を要している．例えば，高知自 動車道は，未だ完全復旧はしていない(2019 年 5 月現在). こうした長期的な道路閉塞が発生した場合，通行車両は， 被災から復旧までの間に迂回を強いられることになり，

人々の移動や物流入影響寸る. 災害時の迂回路の場所や その迂回の原因が把握できれば，被災から復旧までの間 の迂回路への交通誘導や今後の迂回ルートの整備に役立 つ. しかし，現状，道路管理者加，西日本豪雨災害時 の道路閉塞による迂回に関する情報は報告されていない． こうした道路閉塞による迂回を把握寸るセンサーとして, プローブデータがある. しかし，迂回を把握するには， 道路管理者が事前知識として, 平常時の膨大なプローブ 車両軌跡を目視で確認し，経路特性を学習した上で，災 害時の車両軌跡を分析して迂回を把握する必要があり， 労力を要する. そこで, 本研究では, 商用車プローブデ
一タ 1)を用いて，西日本豪雨時の迂回を効率的に検出寸 る方法を提案する. 迁回の検出にあたって, まず，対象 とする迂回を定義する．本研究では，交通影響が大きい と想定される災害時特有の迁回を対象とする. よって, 迁回の要件を “長距離トリップかつ, 平常時よりも時間 と距離が長い遠回りの経路，ならびに平常時と比べて， 主な利用路線が変更されている経路” と定義する。この 迂回検出は，機械学習技術の一つである One-class support vector machine (OCSVM $)^{2,3)}$ を用いる. OCSVM を用いた理 由であるが，本研究のように異常事象が希なために教師 データがない場合の外れ值検出は，「教師なし学習によ る外れ值の検出」に位置づけられる. そのため, 教師あ り学習による分類手法 (e.g. ロジスティック回帰, $\mathrm{SVM}^{23)}$ ) は使えない，既往の教師なし学習による外れ值 検出手法は, ホテリング $\mathrm{T}^{2}$ 法や MT 法（マハラノビ ス・タグチ法) 3)がよく使われているが，これらは「正 常状態のデータは，正規分布に従う」といった強い仮定 をおいている. 本研究で扱うデータを分析した結果，卜 リップの距離や時間のデータは正規分布に従っていると はいえず，ホテリング $\mathrm{T}^{2}$ 法や MT 法を適用することは できない（詳細は，4 章参照）。その他，密度比推定に 
よる異常検知(e.g.カーネル平均適合法, Kullback-Leibler importance estimation procedure ; KLIEP $\left.{ }^{24}\right)$ がある.この手法 は，異常が含まれていない平常時のデータ集合と異常が 含まれるデータ集合の確率密度の比を評価することによ り異常検出を行うアプローチである. 密度比推定は，大 量のデータ, 高次元かつ複雑なデータ分布に適用できる 特徽を持つ. しかし, 本研究で評価する特定 OD間の卜 リップは, サンプル数が少ない場合があり, 密度比推定 時の䛊差が大きくなることが懸念される（例えば， 6 章 で分析する宇和島市〜松山市間の災害時のトリップ数は, 13 サンプルしかない）。なお，災害時の経路を平常時 に観測された経路集合とマッチングを行い，一定距離以 上重複しないものを迁回として判別することも考えられ るが，その場合，経路の重複の閾值を経験的に決定する 必要がある. 一方, OCSVM は, 制約のないノンパラメ トリックな手法であること, 密度比関数の形が未知であ っても，境界さえ探し出せば外れ值を検出可能であり， 少ないサンプルでも適用可能であること, システマティ ックに閾值が推定可能であるため, 本手法を採用した. 機械学習の技術を用いれば，前述した迂回検出時に道路 管理者が事前知識を学習する部分を支援できると考える。

本論文の構成を述べる. 2 章では, 既往研究と本研究 の貢献を整理する. 3 章では, 西日本豪雨時の被災の概 要を述べる. 4 章では, 災害時のトリップの基礎分析を 行う. 5 章では, 迂回検出の方法を述べる. 6 章では, 商用車の迁回を検出するとともに，迂回原因を分析する. 7 章では, まとめと今後の課題を述べる.

\section{2. 既往研究}

本章では，突発事象や災害時を対象とした“経路選択 行動の分析” および “プローブデータを用いた交通分 析”の視点での既往研究と本研究の貢献を整理する.

\section{（1）突発事象・災害時の経路選択行動の分析}

突発事象時 (e.g.工事・事故・渋滞) の情報提供と経路 選択行動の関係を分析している研究は, 日下部ら ${ }^{4)}$,

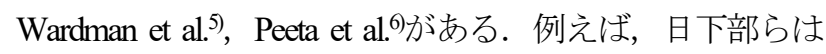
$\mathrm{SP}$ 調査により, 都市内高速道路での突発事象時を対象 に VMS（Variable Messege Sigin, 可変情報板）の情報提供に よる交通行動を調查している. 分析の結果, 渋滞の増加 傾向や料金の情報が経路選択に影響寸ることを明らかに している. いずれの研究も SP 調査により交通行動を調 査していること，その結果を用いて経路選択モデルを構 築し，交通行動を分析している点が共通している.

災害時の経路選択行動を分析した研究は, 森井ら》, 朝倉 ${ }^{8}{ }^{8}$, 藤田・三田村 9)がある. 森井らは, 豪雨発生
時のカーナビでの情報提供を想定し, web アンケートに より交通行動を調査している. 調査結果を用いて, 多項 ロジットモデルにより経路選択行動をモデル化している. 分析の結果, 豪雨の範囲(リスク)の情報が, ドライバー の経路選択（危険を回避する行動）に影響寸ることを明 らかにしている，朝倉らは，台風被害によって通行規制 された四国を対象に，アンケート調査により交通行動を 調查している. 分析結果より, 通行規制に遭遇しても 85\%のドライバーはトリップを中止せずに迂回している ことや通行規制時のトリップの中止・迂回・待機は，所 要時間が影響していることを明らかにしている. 藤田ら は, 東海集中豪雨を対象に, アンケート調査により交通 行動を分析している. 分析結果より, 災害時は, 面的な 渋滞が発生したため, 抜け道のような経路は存在しなか ったことを明らかにしている。

上記の研究は全て一般車両を対象にしており, 商用車 の経路選択行動は明らかになっていない，また，交通行 動把握のために実施している SP 調査やアンケート調査 は，回答が被験者の記憶に依存するといった課題がある. 一方, 携帯電話やカーナビ等から収集されるプローブデ ータは，ネットワークのトリップの経路や速度を詳細に 把握することができる．次節では，プローブデータを用 いた事故・災害時の交通分析に関寸る研究を整理する。

\section{（2）プローブデータを用いた事故・災害時の交通分析}

プローブデータを用いて災害時の交通実態を把握した 研究には， Bengtsson et al..$^{10)}$, Lu et al. ${ }^{11)}$ おび Hara and Kuwahara ${ }^{1,2)}$, Kawasaki et al. . $^{13)}$ 等がある. 例えば， Hara and Kuwaharaは, 2011 年 3 月の東日本大震災の石巻市を対象 にプローブデータを用いて, 津波避難の車両集中による グリッドロック現象（面的な渋滞）の発生過程を明らか にしている. Kawasaki et al.は, 2016年 4 月の熊本地震に おいて, 九州自動車道の通行止めの影響を受け, 福岡方 面から熊本中心部一の代替経路の日中の旅行時間が平常 時に比べて大きく増加したこと等を明らかにしている. 以上よりプローブデータは災害時の交通実態の把握に有 効なデータと考えられる.

次に, プローブデータを用いた異常検出に関する研究 を述べる. 関塚ら ${ }^{14)}$, Asakura et al. ${ }^{15}$ は，事故時の異常検 出を試みている. 具体には, 交通障害発生時の二次元 (時間 $\times$ 走行距離) 上の車両軌跡の変曲点間をつないだ衝 撃波面に着目し，交通障害発生の時間と場所を推定して いる. プローブデータをクラスタリングすることで異常 検出を行っている研究に Cai et al.10や日下部 ${ }^{17 か ゙ あ る . ~}$

Cai et al.は, 交差点付近で観測された, 平常時と異常挙 動の車両軌跡が属するクラスタを構築し, 新たに得られ た軌跡が異常挙動のクラスタに分類された時, その軌跡 を異常挙動軌跡として判断している. 日下部は, 第3 次 
メッシュ $(1 \mathrm{~km}$ 四方 $)$ を最小単位とし，メッシュごとの平 均旅行時間を各日・時間帯ごとのベクトルとして作成し ている，そのベクトルに対して，メッシュごとに kmeans+法を用いたクラスタリングを行い，異常が生じ たメッシュや日時を特定している．以上のように事故や 災害時の異常検出を試みた研究は複数あるが，これらの 研究は，災害時の迂回検出は対象としていない。

災害時の迂回路検出を試みた研究に Yoshida et al. ${ }^{18)}$, Umeda et al.19がある. Yoshida et al.は平常時と災害時にリ アルタイムに収集される三次元プローブ軌跡データの類 似度を評価する Time space distanceやレーベンシュタイン 距離といった指標を提案している. Umeda et al. ${ }^{12)}$ は, 迁 回検出の評価指標として経路の平常時距離と災害時の距 離の比を用いた迂回率を提案している. しかし, これら の研究は, 著者らの感覚から設定した閾值(判定基準)に よる迂回検出や迂回率が最大のルートのみを評価すると いったアドホックな方法で分析しており, 迂回検出のた めの闇值の設定や作業効率化が課題となっている.

既往研究と比べて, 本研究は, 機械学習の技術を活用 し，迂回を効率的に検出している点，および商用車を対 象にした災害時の迂回の分析を行っている点が異なる.

\section{(3) 本研究の貢献}

既往研究を踏まえ, 本研究の貢献を述べる.

1) 迂回検出の効率化: 本研究では, 機械学習技術の 一つである OCSVM を用いた迂回検出方法を提案 した. OCSVM は, 予め, 平常時のトリップの所要 時間，距離のデータを学習しておけば，災害時の 迂回の候補を自動で検出することができる．西日 本豪雨のように，広範かつ同時多発的に被災が発 生し，復旧に時間を要する場合には，迂回等の交 通実態の迅速な把握が求められる。こうした状況 下において，機械学習技術による迂回検出の効率 化は，道路管理者の業務支援に資すると考える.

2) 商用車の迁回の実態把握および迁回原因の解明 : 迂回検出の結果, 被災路線の直近の迂回路が通行 可能であっても，直近の迂回路を使わずに，大き く迂回する車両が確認された。迂回原因を分析し た結果，交通障害の “リスク”が一因であること が示唆された.

\section{3. 西日本豪雨災害時の愛媛県の被災概要}

ここでは，四国地方において特に被害の大きかった愛 媛県の被害概要を述べる．まず，降雨の状況を述べる．

図-1 に愛媛県松山市，宇和島市の降水量の推移を示寸. 同図に示寸ように, 7 月 4 日から日降水量が増加し，7
月 6 日，7日にピークを観測している. 松山では，7月 7 日に最大 $206 \mathrm{~mm} /$ 日を観測している.7月 8 日には, 愛媛 県と高知県に大雨特別警報が発令されている. 本研究で はこの日降水量の推移を参考に災害の期間を平成 30 年 7月 4 日から 7 月 10 日の 1 週間，比較する平常時の期間 を災害発生前の 6 月 20 月から 26 日として設定した.

道路損傷の状況を述べる. 図-2に 7月 4 日〜 10日の間 に発生した規制箇所を示寸，図-2(a)に示寸ように規制箇 所は広範に多数存在している. 愛媛県庁によると, 県の 管理道路 16 箇所，市町村の管理道路 78 箇所が道路全面 通行止めとなったとの報告(2018 年 10 月 15 日時点)があ る ${ }^{20)}$. 高速自動車国道の被苂に着目寸ると, 松山自動車 道では，大雨により大洲市の肘川が汇濫し，図-2(b)に示 寸大洲 IC が浸水した，そのため，7月 6 日〜8 日にかけ て, 通行止が発生した. また, 愛媛〜高知間を縱断する 高知自動車道の立川橋(図-2(c))では，7月７日末明，上り 線で大規模な土砂災害が発生し，全面通行規制が行われ た. 同区間では，2018 年 7 月 13 日に下り線を利用した 対面通行で通行を再開したが，いまだ完全復旧はしてい ない, なお, 高知自動車道の被災は, 国から重篤被災箇 所として指定されている.

\section{4. 豪雨災害時の交通状況}

本章では，商用車プローブデータ 1)を用いて，豪雨時 のトリップの基礎分析を行った. プローブデータは, 予 め, エンジン ON/OFF 等の区切りで GPS データをトリ ップ単位に分割処理されたものを用いた.

\section{(1) 四国全域のトリップ分析}

四国内のトリップの分析結果を述べる. 図-3 に平常 時, 災害時の日平均トリップ数を示す. 平常時に比べて 災害時のトリップ数が減少している. 次に，図-4に平 常時，災害時のトリップ距離，トリップ時間のヒストグ

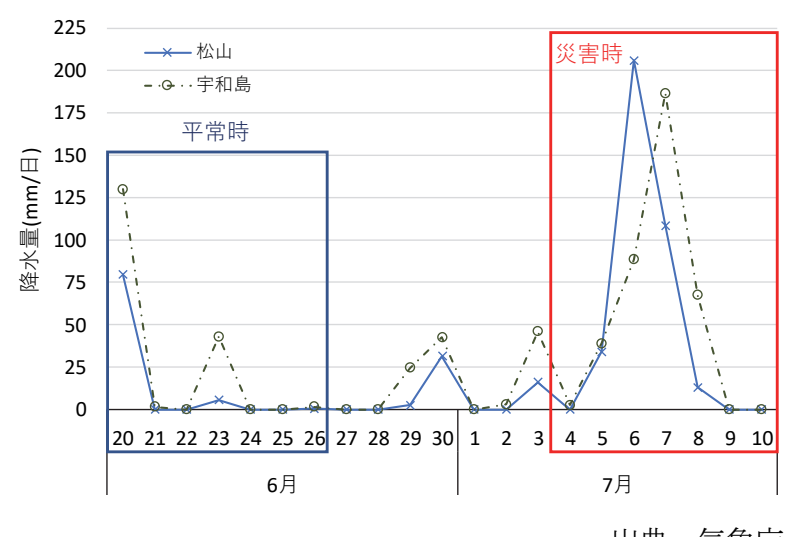

図-1 降水量の推移（観測 ; 愛媛県松山市，宇和島市） 


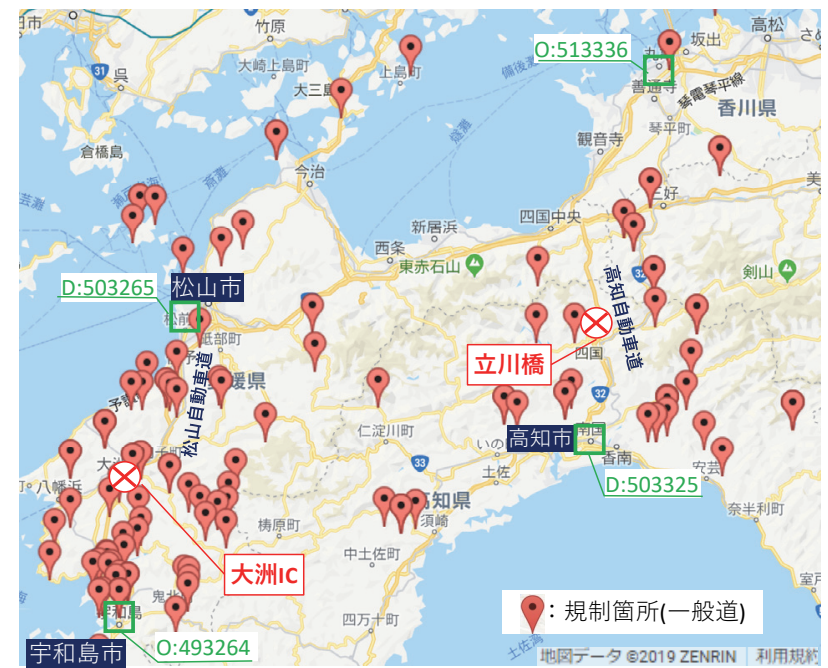

(a) 一般道の規制箇所の広域図

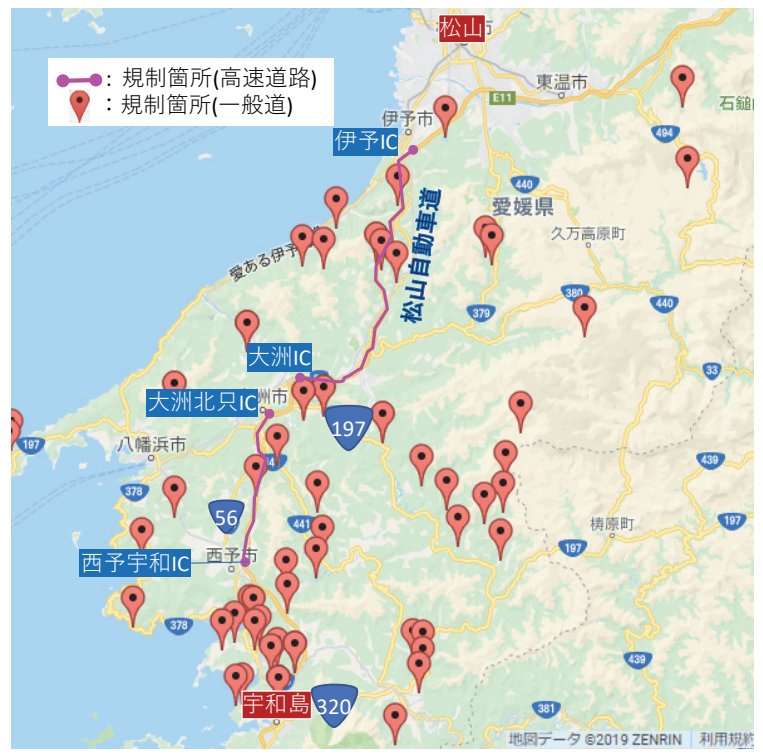

(b) 松山自動車道・大洲 IC 周辺の規制箇所

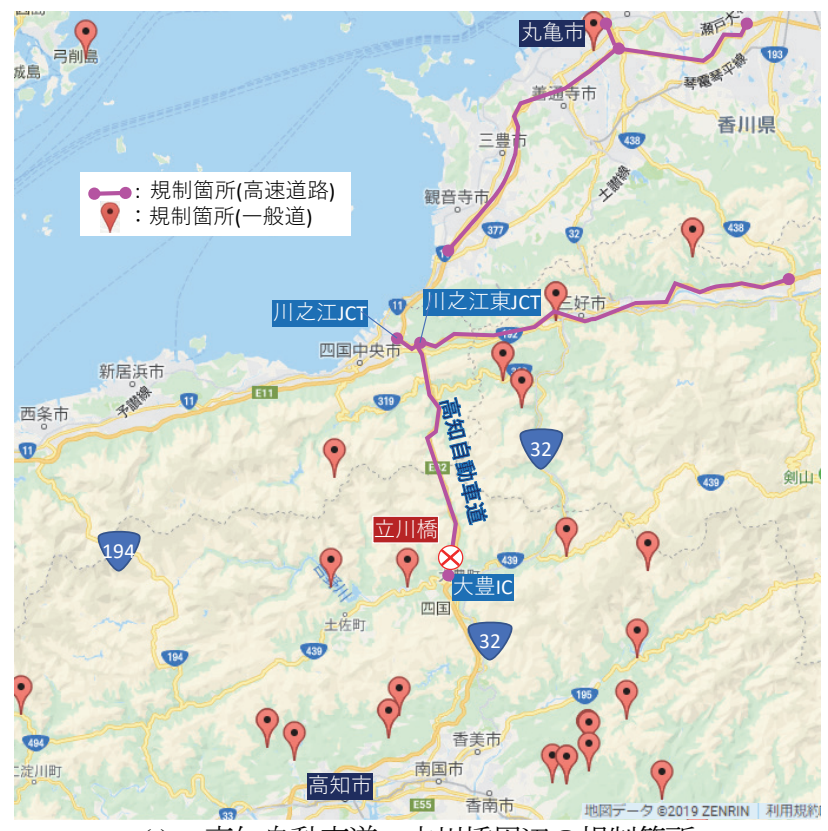

(c) 高知自動車道・立川橋周辺の規制箇所

図-2 豪雨による規制箇所[2018年 7月 4 日〜 10日]

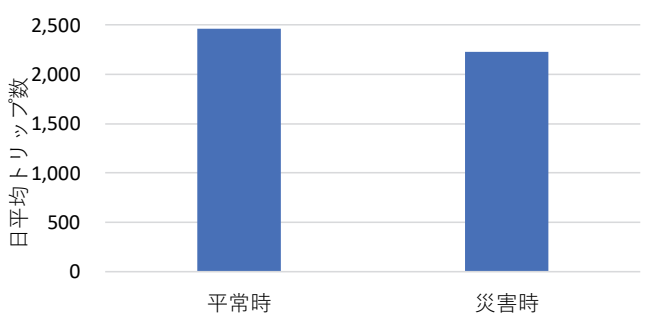

図-3 四国内の日平均トリップ数の比較

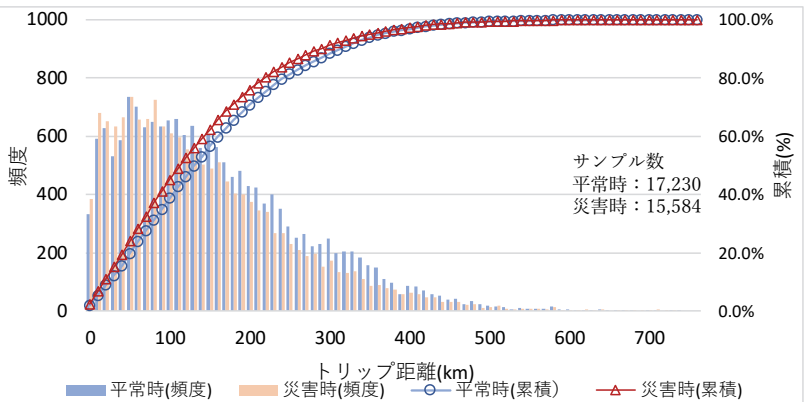

(a) トリップ距離

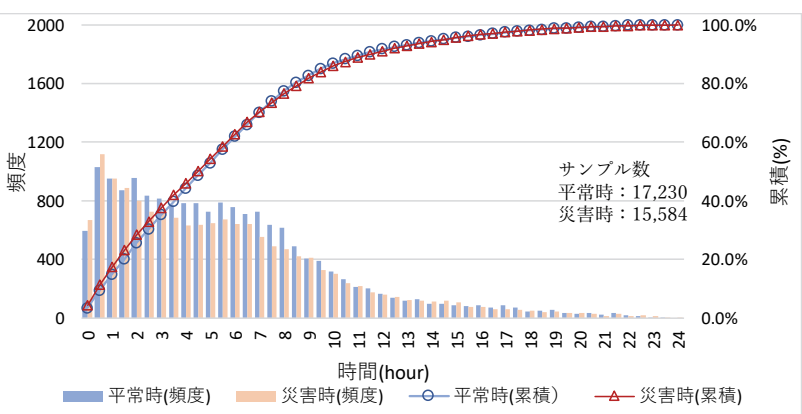

(b) トリップ時間

図-4トリップ数のヒストグラム・累積分布[四国内]

ラム・累積分布を示す. トリップ距離は， $5 \mathrm{~km}$ 間隔，卜 リップ時間は 30 分間隔で集計している．災害時のトリ ップ長を見ると, 平常時に比べて短距離(100km 未満)の トリップが増加している. トリップ時間を見ると，災害 時には，短時間のトリップが増加している. 分析前は, 豪雨時に迂回が発生すれば，トリップ距離，トリップ時 間は長くなる傾向が表れると想定していたが，そのよう な傾向はみられなかった。この理由は，豪雨による被災 を警戒し，長距離トリップ関連の業務を控えたためと推 察される。しかし，災害時に規制区間を通過する必要の あった長距離トリップのみに着目すれば，迂回によるト リップ距離, 時間の増加が発生したと考える. そこで, 次節では，特定の起終点に着目した分析を行う。

\section{(2) 特定トリップに着目した分析}

分析対象としたトリップは，土砂災害の発生した高知 自動車道上りを通過する可能性が高い長距離トリップ （距離 $100 \mathrm{~km}$ 以上），かつ，比較的トリップ量の多い ものを選定した．選定の結果，図-2 に示寸香川県丸亀 市から高知県高知市 (2 次メッシュ番号 513336, 503325) 間 


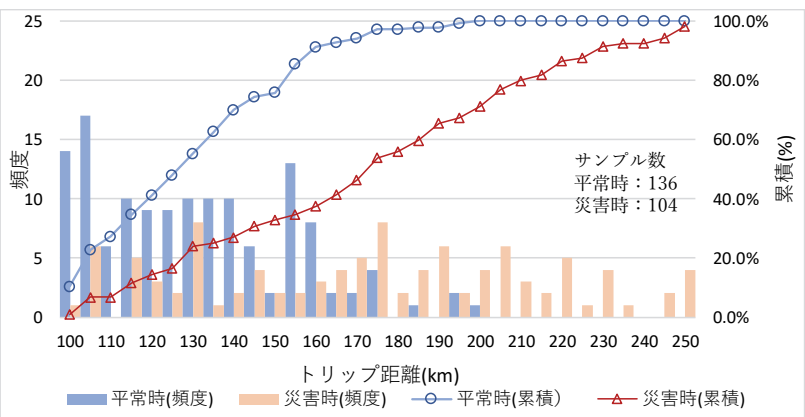

(a) トリップ距離

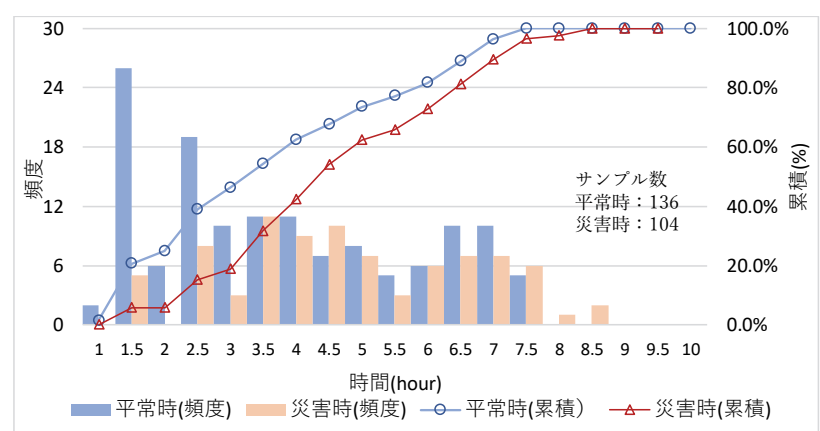

(b) トリップ時間

図-5 トリップ数のヒストグラム・累積分布[丸亀市-高知市 $]$

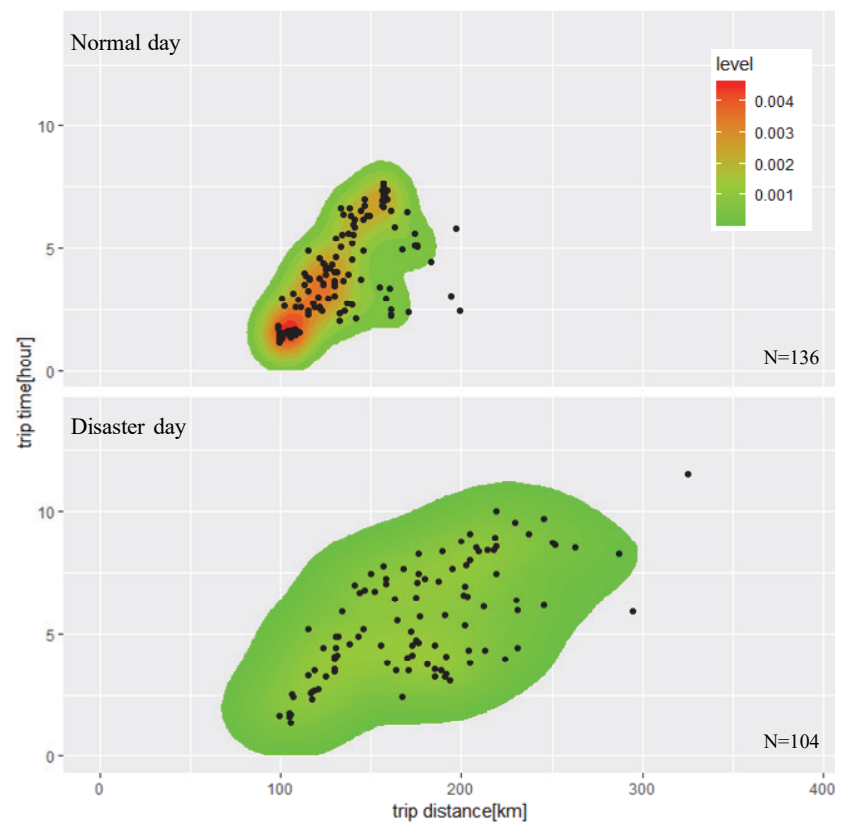

図-6 トリップ距離，時間のヒートマップ[丸亀市-高知市]

のトリップを分析対象とした. 図-5 に丸亀市〜高知市 間のトリップ距離，トリップ時間のヒストグラム・累積 分布を示寸. 災害時は, トリップ距離, トリップ時間と もに増加する傾向がみられる. 図-6 にトリップ別の距 離，時間の散布図のヒートマップを示す，同図を見ると， 平常時と災害時で分布が明らかに異なる. 平常時は, 卜 リップ距離 100〜150km 程度，トリップ時間 2〜5 時間程 度が多い，一方，災害時は，トリップ距離が最大 $300 \mathrm{~km}$ を超えるものやトリップ時間が 10 時間以上のものもみ

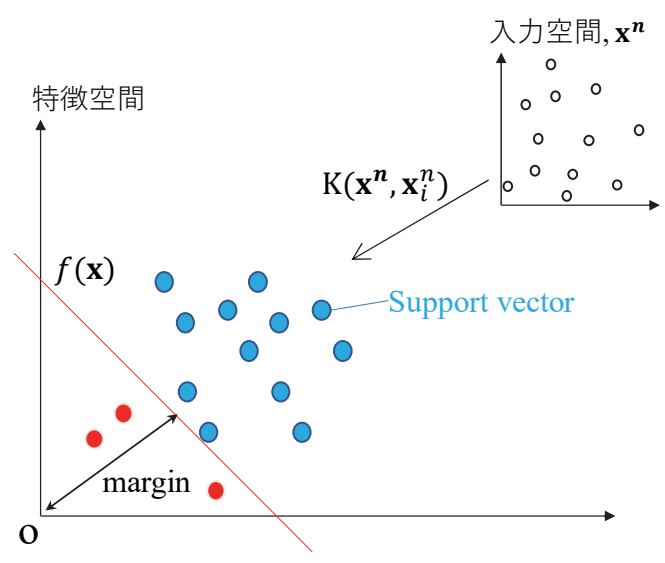

図-7ＯCSVMのイメージ

られ，迂回しているトリップが含まれていると思われる. このデータから, 人間が, 平常時と災害時を見比べて迁 回を検出するのは困難である，そこで，次節で OCSVM を用いた迂回を効率的に検出する手法を述べる.

\section{5. 迂回の検出方法}

本章では, 迂回検出の方法を述べる. 迂回検出は, (1)前処理, (2)迁回候補の検出, (3)迁回候補の精査の 3 ス テップで構成される. 以降に, ステップごとの処理内容 を述べる．また，最後に，迂回検出の性能評価指標につ いて定義する.

\section{(1) 前処理}

前処理では, マップマッチング, 配送データの除外を 行った. ここで, マップマッチングとは, 位置データか ら道路ネットワーク上の移動した経路（道路）を特定す ることである. 配送データの除外の理由とその除外法を 述べる．商用車は，配送業務により最終目的地までにい くつかの地点に立ち寄る場合がある. 配送のデータは, 複数のトリップが混在するため, 1 章で定義した要件の 迁回を検出するためには, 配送の影響を出来るだけ低減 する必要がある. そこで, 本研究では, トリップ途中で, $m$ 時間以上停止している車両を配送と判定し, 解析デー タから除外することとした. 本研究では, $m=30$ 分に設 定し，配送の除外処理を行った.

\section{（2）迂回候補の検出}

迂回の候補を検出する方法を述べる. 本研究では, One-Class Support Vector Machine (OCSVM) 2), 3)を用いた. OCSVM を用いた異常検知に関する既往研究は, 水力発 電所の異常の予兆発見 (小野田 ${ }^{21}$ ) や歩行者軌跡を用い た行動識別（豊嶋ら 22)）がある.

まず，OCSVM を概説する. 平常時のベクトルデータ 
を $\mathbf{x}^{n}$ と表記する. OCSVM のイメージを図-7 に示す. 同図に示すように OCSVM は，カーネル関数 $K\left(\mathbf{x}^{n}, \mathbf{x}_{i}^{n}\right)$ を用いて，入力空間のデータ $\mathbf{x}^{n}$ を特徵空間に写像する. 写像されたデータを Support vector という. 次に原点から Support vector までの距離(margin)を最大にするような関数 $f(\mathbf{x})$ を推定する. この $f(\mathbf{x})$ が，データの正常／異常を 識別する関数である. OCSVM は，新たに得られた $i$ 番 目データ $x_{i}^{d}$ に対して,

$$
\delta_{i}= \begin{cases}0, & f\left(x_{i}^{d}\right)>0 \\ 1, & f\left(x_{i}^{d}\right)<0\end{cases}
$$

と識別する．ここで， $\delta_{i}$ は，データの正常／異常を示 す変数であり, $\delta_{i}=0$ の場合を正常, $\delta_{i}=1$ の場合を異常 と定義する. 異常の場合, 図-7 の赤丸のように $f(\mathbf{x})$ よ りも原点に近い箇所に写像される.

次に，本研究で OCSVMに入力するトリップデータを 定義する. トリップのインデックス集合を $[n]$ と定義す る. $i \in[n]$ 番目トリップの距離を $l_{i}$, トリップ時間を $t_{i}$ と表記する. 平常時のトリップデータの集合を以下のよ うに定義する。

$$
\begin{gathered}
x_{i}^{n}=\left(l_{i}, t_{i}\right)^{T}, \\
\mathbf{x}^{n}=\left(x_{1}^{n}, x_{2}^{n}, \ldots, x_{i}^{n}, \ldots, x_{I}^{n}\right)^{T} .
\end{gathered}
$$

同様に，災害時に得られたトリップデータ集合を $\mathbf{x}^{d}$ と し，その $i$ 番目の要素を $x_{i}^{d} \in \mathbf{x}^{d}$ と表記する。迂回候補 の検出には，まず，平常時のトリップデータ $\mathbf{x}^{n}$ を用い て, 識別関数 $f(\mathbf{x})$ のパラメータを学習する. そして, $\mathbf{x}^{d}$ をパラメータ学習済の $f(\mathbf{x})$ に入力し, 異常と判定さ れたものを迂回として検出する. 本研究の OCSVM は既 往のモデルを活用したものである，そのため，本文中で は, OCSVM の定式化やパラメータ推定の内容は, 割愛 し，付録に記載する.

\section{（3）迂回候補の精査}

(1)(2)の処理後データにも，配送等のデータが含まれ る場合がある、そのため, 迂回検出されたデータについ ては，車両軌跡データを精査し，トリップ途中において， 最終目的地以外一立ち寄り（物流施設付近での一時停車 や不自然な U ターン等）が見られるものを配送のトリ ップと判断し, 迂回から除外する処理を行った.

\section{（4）迂回検出性能の評価指標の定義}

本節では，提案手法による迂回検出の評価指標を定義 する. 迁回検出精度の評価指標は, Precision(適合率)と
表-1 モデルと実際のトリップの迂回/平常の関係

\begin{tabular}{|c|c|c|c|}
\hline \multicolumn{2}{|c|}{} & \multicolumn{2}{|c|}{ 実際のトリップ } \\
\cline { 3 - 4 } モデル & 迂回 & 平常 \\
\hline \multirow{3}{*}{ モテ回 } & $\begin{array}{c}\text { TP } \\
\text { (True Positive) }\end{array}$ & $\begin{array}{c}\text { FP } \\
\text { (False Positive) }\end{array}$ \\
\cline { 2 - 4 } & 平常 & $\begin{array}{c}\text { FN } \\
\text { (False Negative) }\end{array}$ & $\begin{array}{c}\text { TN } \\
\text { (True Negative) }\end{array}$ \\
\hline
\end{tabular}

Recall (再現率)およびF值を用いることとした25). Precision とRecallは情報検索の有効性を示す評価指標として使わ れており，Precisionは検索結果に適合データがどれだけ 含まれるかを示す適合率である. Recallは，適合データ 全体のどれだけが検索結果に含まれているかを示すもの である、そしてPrecisionとRecallの調和平均が，F值であ る. 一般に, PrecisionとRecallは，トレードオフの関係に ある、そしてF值が高ければ，モデルの性能が良いこと を意味する. Precision, Recall, F值を以下に定義する. まず，モデルと実際の経路の迁回/平常(迂回ではない)の 関係を表-1のように定義する。表中のTP，FP，FN，TN は，各々に該当するトリップ数である. 既往文献 ${ }^{25)} り$, PrecisionとRecallおよびF值を以下に定義する.

$$
\begin{gathered}
\text { Precision }=\frac{\mathrm{TP}}{\mathrm{TP}+\mathrm{FP}}, \\
\text { Recall }=\frac{\mathrm{TP}}{\mathrm{TP}+\mathrm{FN}}, \\
\mathrm{F} \text { 值 }=\frac{2 \times \text { Precision } \times \text { Recall }}{\text { Precision }+ \text { Recall }} .
\end{gathered}
$$

\section{6. 迂回車両の検出と分析}

本章では，5 章で述べた方法で，西日本豪雨時の迂回 を検出し，商用車の迂回の原因を分析した．分析対象は， 4 章で分析した香川県丸亀市〜高知県高知市間および愛 媛県宇和島〜松山市間のトリップとした. なお，各トリ ップの起終点(2次メッシュ)の位置は，図-2(a)を参照され たい.

\section{（1）丸亀市〜高知市間のトリップの分析結果}

丸亀市〜高知市間のトリップの分析結果を述べる. 推 定されたパラメータは， $\sigma=0.001 ， v=0.01$ となった. 図-8 に OCSVMによる香川〜高知間のトリップの迂回検出結 果を示す. 図中の白丸は，平常時 (学習) データおよび, 黒丸は災害時の正常ラベル，赤丸は災害時の迂回（異 常）ラベルを付与されたデータである. 前節で述べたよ うにこの迂回検出されたデータを精査し, 図-9 に示す ような配送と思われる 3 トリップのデータを除外した.

図-10に精査後の平常時および災害時の車両経路を示す. 図-10(b)は，迂回(異常)／平常ラベルにより赤／青に色分 


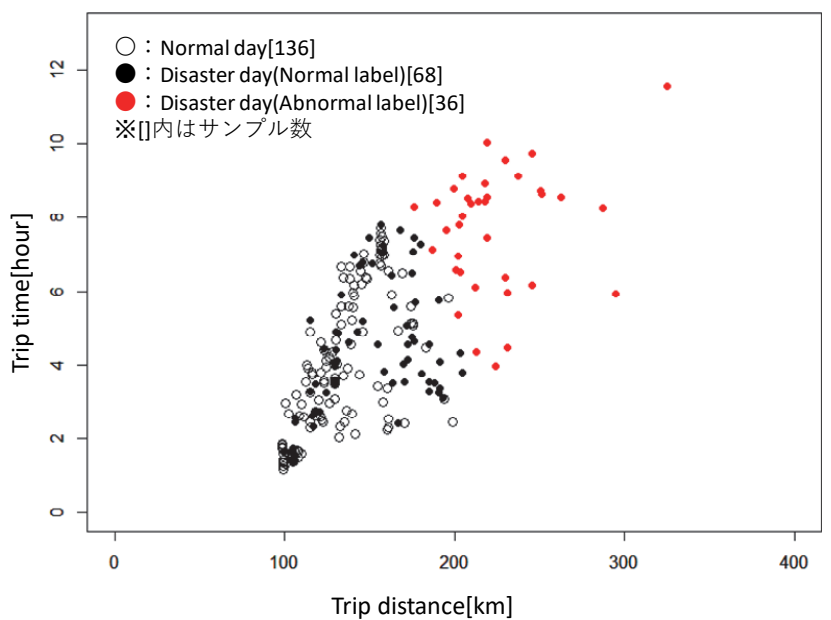

図-8 トリップの迂回候補検出結果[丸亀市-高知市]

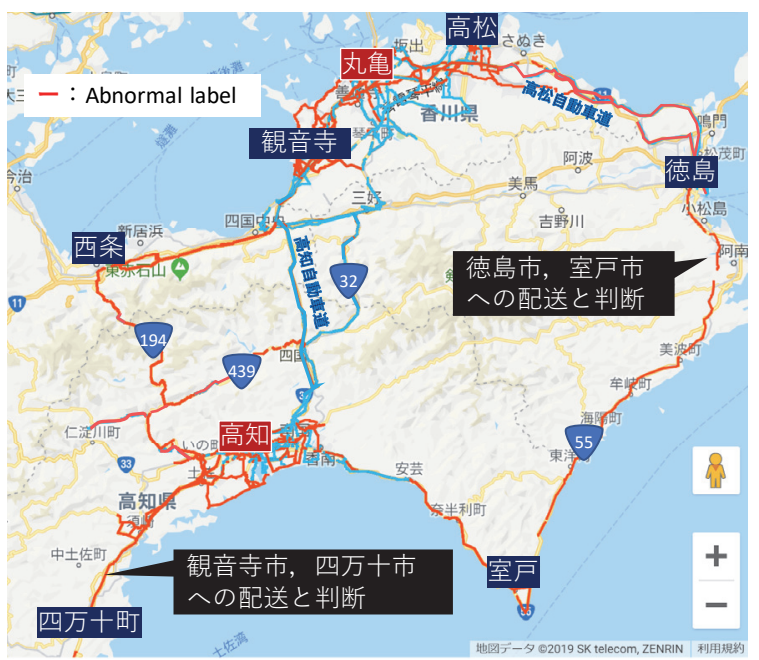

図-9 配送と判断した車両経路の例[丸亀市-高知市]

けしている，平常時の経路（図-10(a)）を見ると，商用 車ドライバーは高知自動車道や国道 32 号を利用してい る。一方，災害時（図-10(b)）は，国道 194 号経由の経 路が出現し, その経路に迂回(異常)ラベルが付与されて いる.この経路は，“長距離トリップかつ，平常時より も時間と距離が長い遠回りの経路，ならびに平常時と比 べて，主な利用路線が変更されている経路”であり，1 章で定義した迂回の要件を満たしていると考える．以上 の迂回の検出結果を表-2 に整理する．なお，同表の実 際のトリップの迂回, 平常は, 分析者によりラベル付け を行った. 同表より $\mathrm{F}$ 值 $=0.96$, Precision $=0.92$, Recall $=1.00$ と なった．よって，本トリップでは， 9 割以上の高い精度 で迂回を検出することができたと思われる，以降，迂回 路の特性を分析する. 経路ごとの分担率を図-11 に示寸. 分担率は，図-10(b)の A-A'断面の経路交通量を集計した。 災害時は，高知自動車道立川橋の被災前後の期間で分け て集計した，同図を見ると，平常時は，約 8 割の商用車 が高知自動車道を利用し，約 2 割の車両が国道 32 号を 利用している。一方，災害時は，国道 194 号利用（迂

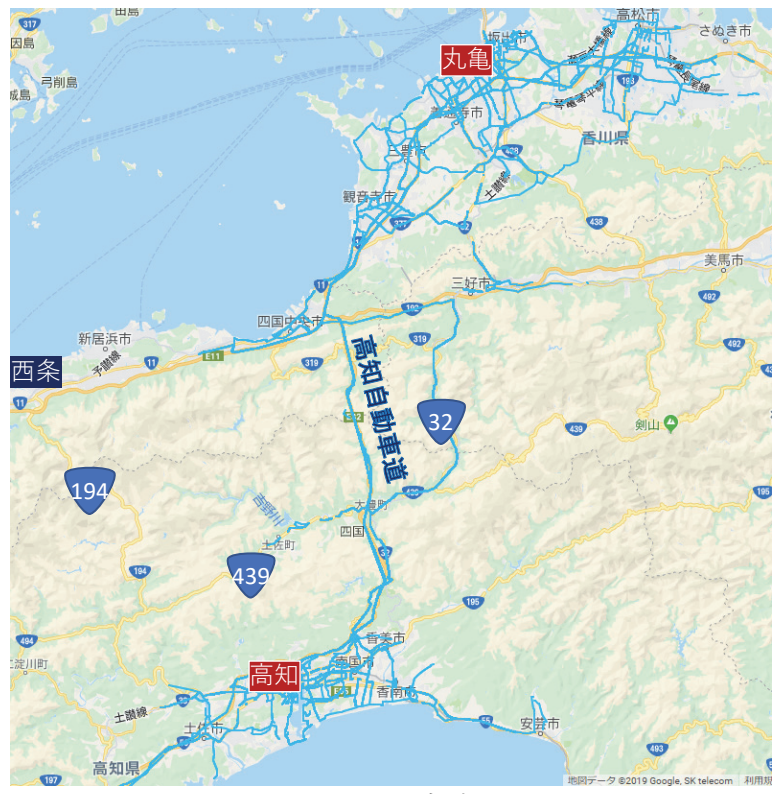

(a) 平常時

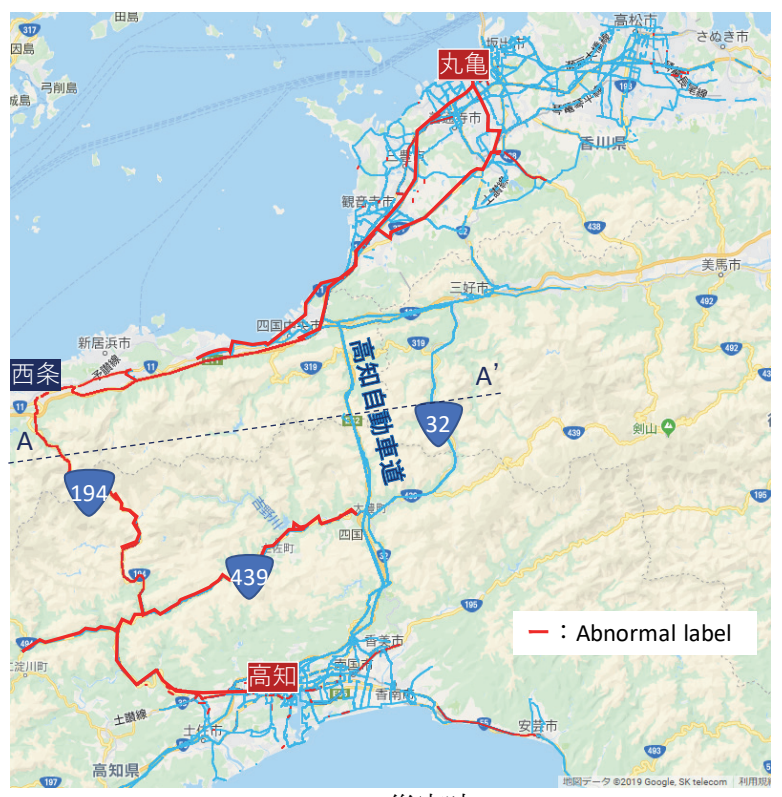

(b) 災害時

図-10 車両経路[丸亀市-高知市]

表-2 災害時の迂回の検出結果（精查後）

\begin{tabular}{|c|c|c|c|c|}
\hline \multicolumn{2}{|c|}{} & \multicolumn{2}{|c|}{ 実際のトリップ } & \multirow{2}{*}{ 計 } \\
\cline { 3 - 5 } & 迁回 & 平常 & \\
\hline \multirow{2}{*}{ モデル } & 迂回 & 33 & 3 & 36 \\
\cline { 2 - 5 } & 平常 & 0 & 68 & 68 \\
\hline \multicolumn{2}{|c|}{ 計 } & 33 & 71 & 104 \\
\hline
\end{tabular}

回）が増加している．特に，立川橋被災後は，顕著に増 加しており, 約 4 割が国道 194 号を利用している. 図12 に経路ごとの平均所要時間を示す。これを見ると, 災害時には，国道 194 号経由は，国道 32 号経由よりも 1 時間程度所要時間が長いことが確認される。また，交通 規制を確認した結果，災害時において高知自動車道以外 の国道 32 号，国道 194 号の経路は規制されておらず， 


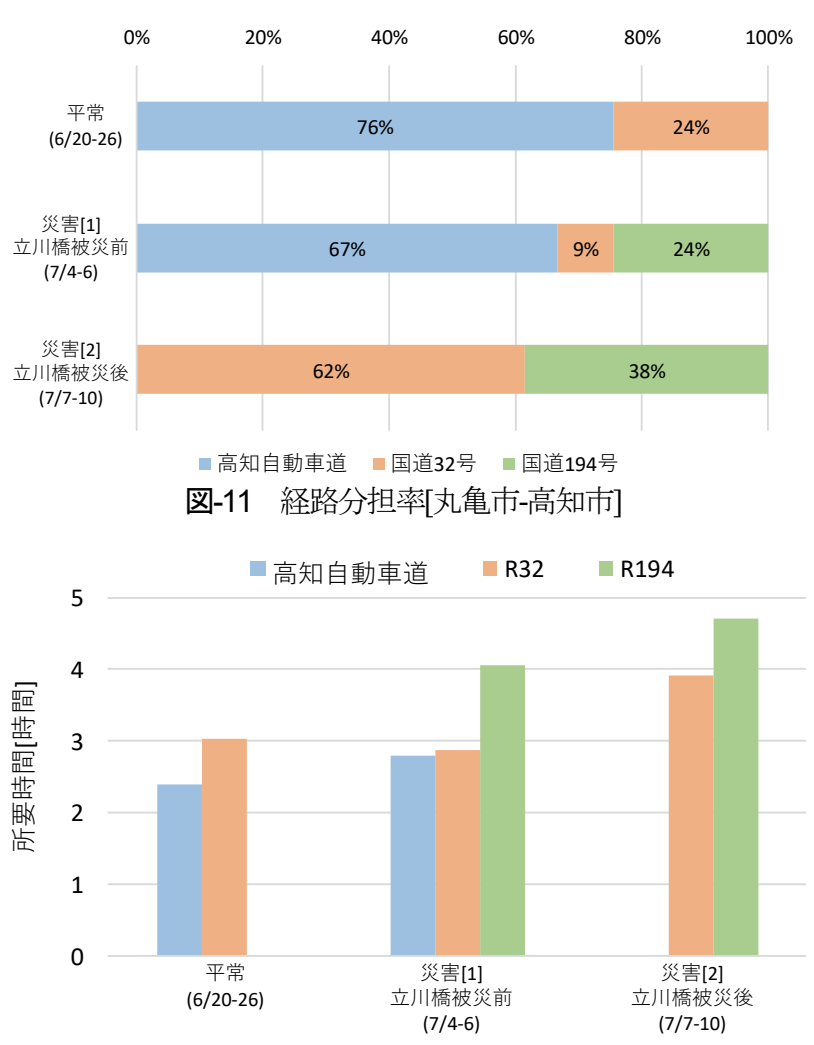

図-12 平均所要時間[丸亀市-高知市]

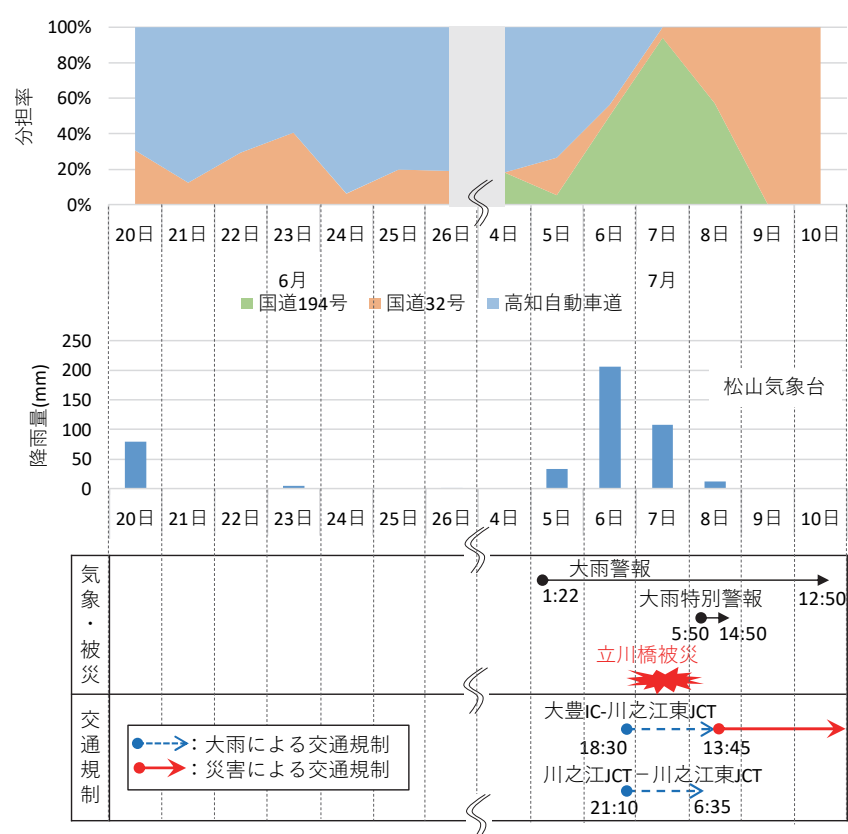

図-13 経路分担率と誘因のタイムライン[丸亀市-高知市]

通行可能な状況であった．以上より，商用車の 4 割は, 災害時に，国道 32 号が通行可能にもかかからず，所要 時間の長い（非合理的な）国道 194 号へ迂回しているこ とが確認された．この迂回の原因特定のために，迂回の 誘因と思われる気象，被災，交通規制，地形との関係を 分析する. 図-13 に経路分担率と誘因データのタイムラ インを示す．同図を見ると，7月 6 日からの高知自動車 道の規制, 7 日の立川橋被災や大雨特別警報発令にあわ せて国道 194 号の分担率が高まっている．図-14に立川

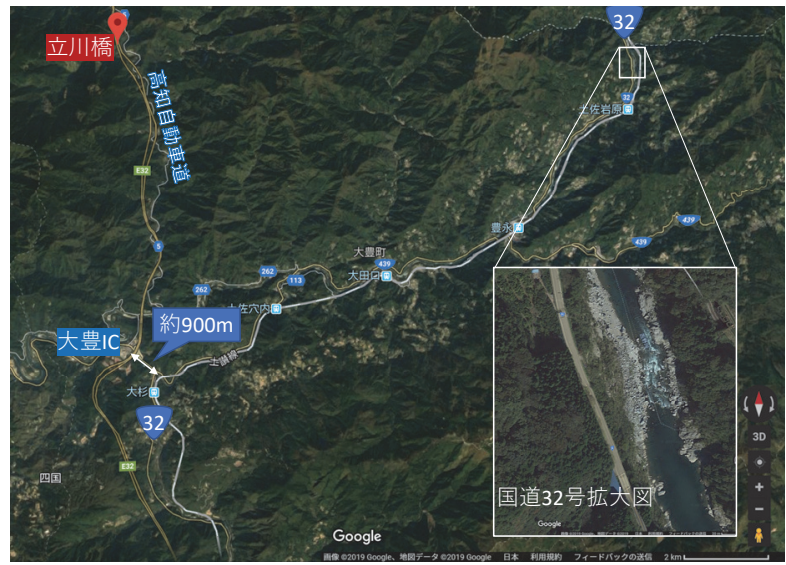

図-14 立川橋周辺の地形

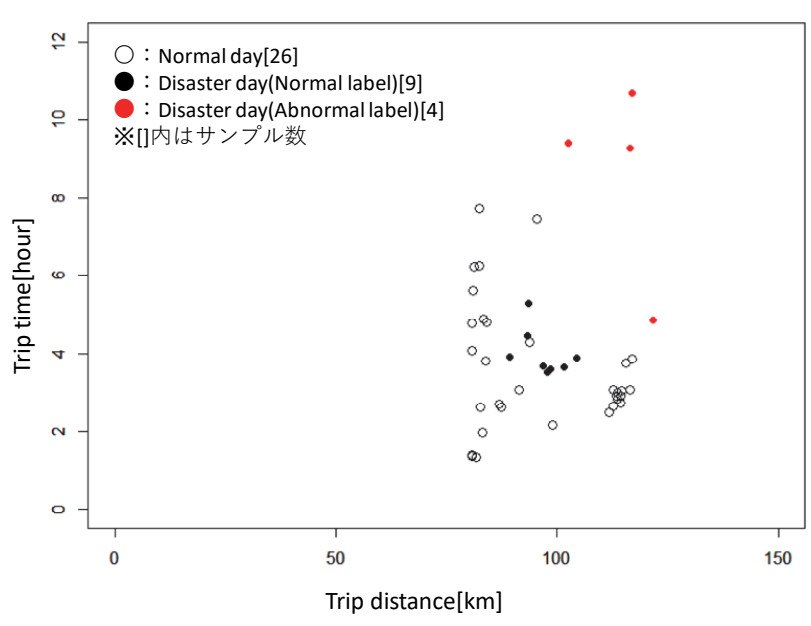

図-15 トリップの迂回判別結果[宇和島市-松山市]

橋周辺の地形を示す．同図に示寸ように国道 32 号は, 山の斜面に沿って整備されており，かつ，被災した高知 自動車道の立川橋とも近い. 以上の状況を踏まえると, 大雨時のドライバーは, 国道 32 号は, 通行できるもの の，大雨により，高知自動車道と同様に被災するかもし れないといった交通障害の “リスク（危険度）”を警戒 し，国道 194 号へ迂回したと推察される. なお，リスク がドライバーの経路選択に影響を与えるという結果は, 森井らの研究成果と一致する.

\section{（2） 宇和島市〜松山市間のトリップの分析結果}

宇和島市〜松山市間のトリップの迂回を分析する. 推 定されたパラメータは， $\sigma=0.012 ， v=0.009$ となり，丸亀 市〜高知市間のトリップのパラメータと大きな差はなか った. 図-15にOCSVMによる迂回の検出結果, 図-16に 精査後の平常時/災害時の車両軌跡を示寸. 精査の結果, OCSVM で迁回と検出された経路の中に, 配送と思われ るデータは含まれていなかった．図-15を見ると，明ら かに所要時間や距離の長いトリップが迂回として検出さ れている. 図-16 を見ると, 平常時に選択されていない 遠回りである国道 320 号が过回として検出されている. 一方で，平常時に選択されている国道 56 号線経由の卜 


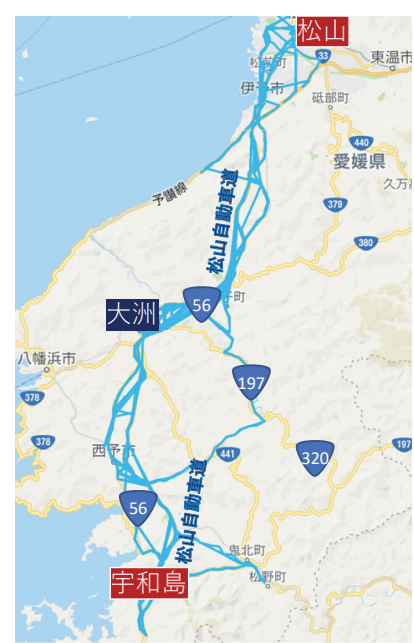

(a)平常時

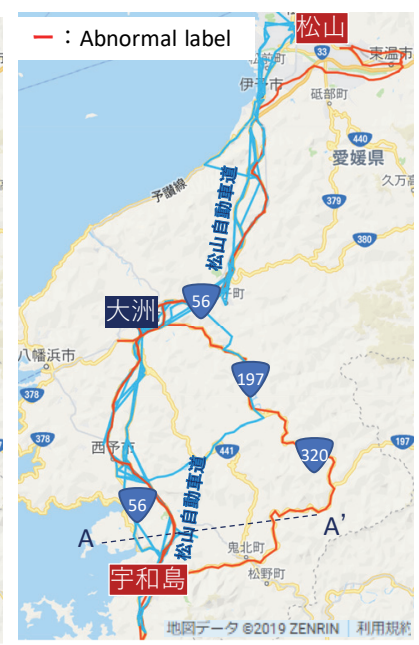

(b)災害時 図-16＼cjkstart車両経路[宇和島市～松山市]

表-3 災害時の迂回の検出結果（精査後）

\begin{tabular}{|c|c|c|c|c|}
\hline & \multicolumn{2}{|c|}{ 実際のトリップ } & \multirow[b]{2}{*}{ 計 } \\
\hline & & 迂回 & 平常 & \\
\hline \multirow{2}{*}{ モデル } & 迂回 & 3 & 1 & 4 \\
\hline & 平常 & 0 & 9 & 9 \\
\hline \multicolumn{2}{|c|}{ 計 } & 3 & 10 & 13 \\
\hline
\end{tabular}

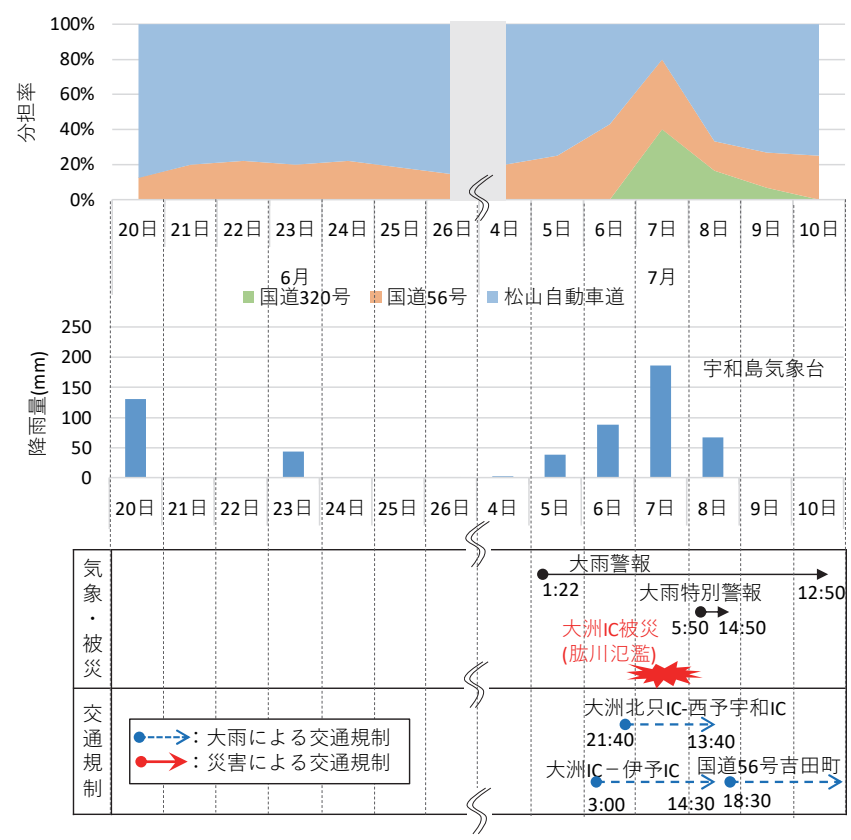

図-17 経路分担率と誘因のタイムライン[宇和島市-松山市]

リップも迂回として検出されている.このトリップデー タを確認した結果，平常時よりも所要時間が長い 1 トリ ップが迁回として検出されていた. 本手法では，このよ うに平常時と経路が重複するものであっても所要時間が 長ければ，「迂回(異常)」として検出する.このような 平常時との重複ルートを迂回と検出しないようにするこ とは, 今後の課題と考える. 迂検出結果を表-3 に示す. 同表より $\mathrm{F}$ 值 $=0.86$, Precision $=0.75$, Recall $=1.00$ となった. 前

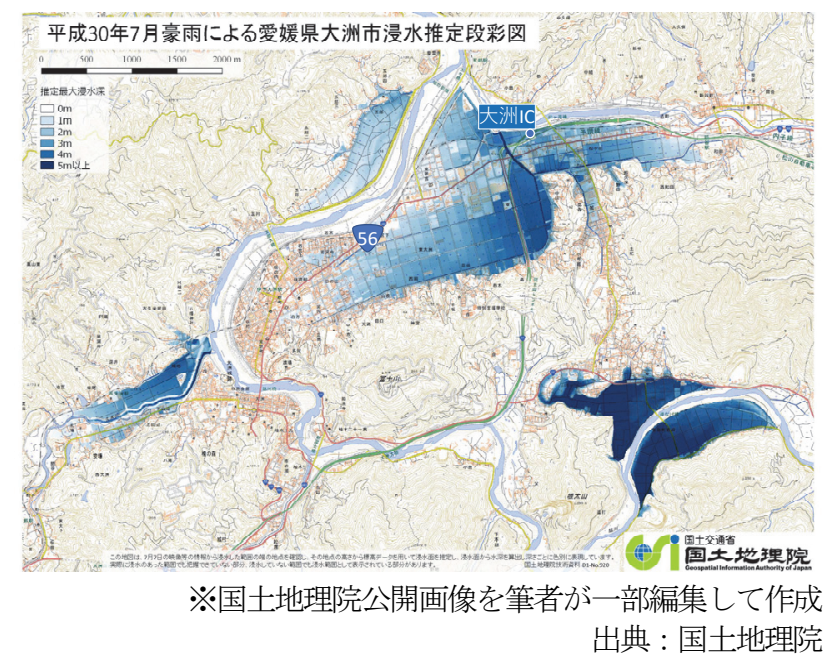

図-18 大洲 IC 付近の浸水推定段彩図

節の丸亀市〜高松市間のトリップよりも $\mathrm{F}$ 值は低いもの の, 約 9 割の精度で迁回を検出できている. 前節と同様 に，国道 320 号への迁回の原因に被災のリスクが関与し ているか分析する. 図-17 に経路分担率と誘因のタイム ラインを示す．分担率は，図-16(b)の A-A'断面の経路交 通量を集計した。同図を見ると，大洲 IC が浸水した 7 月 7 日は，国道 320 号経路の分担率があがっている. 図 -18 に大洲 IC 付近の浸水推定段彩図を示す，これを見る と，国道 56 号も一部浸水範囲となっていることがわか る. 以上より, 高知自動車道の事例と同様に, ドライバ 一は，国道 56 号の交通障害のリスクを警戒し，国道 320 号に迁回したものと推察される. 但し, 災害時の国 道 320 号への迁回トリップが 3 サンプルしか取得されて いないため，本分析結果は参考と考える.

\section{7. おわりに}

本研究では, OCSVM を用いて, 西日本豪雨時の商用 車の迂回を検出するとともに，迂回の原因の分析を行っ た. 検出した迂回の原因特定のために，様々な誘因デー タと組み合わせて分析を行った. 分析の結果から得られ た知見を以下に整理する.

1) OCSVM を活用し，迂回を検出した結果，豪雨時の 商用車ドライバーは, 所要時間の短い合理的な経 路のみを選択するわけではなく，大きく迂回する 場合があることが確認された。例えば，高知自動 車道の被災事例では, 商用車の 4 割は, 高知自動 車道の直近の迁回路である国道 32 号ではなく, 所 要時間の長い国道 194 号へ迂回していることが確 認された.

2) プローブデータとその他の誘因データを組み合わ 
せて分析した結果，商用車の迂回の原因は，交通 障害の “リスク”が一因であることが示唆された。 本分析結果は，豪雨災害の被災時の道路交通管理の検 討課題を示唆するものである. 今後の検討課題を以下に 整理する.

1)災害時の経路選択行動を詳細に分析するためには, プローブデータのみならず，気象，被災ならびに 交通規制といった交通行動の誘因となるデータも セットで収集・蓄積すべきである，現状，災害関 連のデータがセットで蓄積されていないため，本 研究では，関係機関への問い合わせや web 検索等 で個別にデータを収集する必要があった。今後は, 関連するデータを効率的かつ一元的にアーカイブ し，皆が活用できる仕組みの構築が必要と考える。

2）現状，災害時の交通情報は，渋滞状況や所要時間 ならびに規制といった“事実”に関する内容が主 である，今後は，これに加えて，交通障害の“リ スク”を提供し，ドライバーの経路選択を支援す べきである．そのためには，リスクの指標化や情 報提供方法の検討が必要と考える.

3）OCSVM による迂回候補検出の結果，平常時と重複 するルートであっても, 所要時間が長い場合に,

「迂回」と誤検出した例が確認された。この解決 方針としては，例えば，「平常時経路との重複 率」といった，平常時との経路の重複を評価する 指標を追加することが考えられる。

4) 本分析では，西日本豪雨時の四国内トリップにお ける 2 事例の迂回検出を行った. $\mathrm{F}$ 值により評価を 行った結果，本ケースでは高い精度で迂回を検出 することができた．ただし，提案手法のロバスト 性検証のためには，今後発生する災害事例を追加 分析することが必要と考える.

5) 本研究では, 商用車を対象に分析を行った. 今後 は，一般の乗用車のプローブデータを解析し，商 用車と乗用車の経路選択行動の違いを分析する必 要がある.

謝辞 : 本研究は, 独立行政法人情報通信研究機構(NICT) の委託研究「異分野データ連携によるスマートモビリテ イ基盤の研究開発」および国土交通省の「道路施策の質 の向上に資する技術研究開発」の研究テーマ「交通流理 論と AI 学習による非日常の発見とアラート発信」の助 成を受けたものである．また，本研究で使用したプロー ブデータは，富士通交通・道路データサービスより提供 していただいた．ここに記して，感謝の意を表す。

\section{付録I OCSVMの定式化}

ここでは，5 章で示した OCSVM の定式化を概説する. なお，詳細は，参考文献2),3)を参照されたい。

まずカーネル関数 $K\left(\mathbf{x}^{n}, \mathbf{x}_{i}^{n}\right)$ を定義する．カーネル関 数は, これまでに, 様々なものが提案されている. 本研 究では, 以下のガウスカーネル関数を用いた。

$$
K\left(\mathbf{x}^{n}, \mathbf{x}_{i}^{n}\right)=\exp \left(-\gamma\left\|\mathbf{x}^{n}-\mathbf{x}_{i}^{n}\right\|^{2}\right)
$$

ここで， $\gamma$ は，パラメータである．識別関数 $f(\mathbf{x})$ は, 下式のように定義する.

$$
f(\mathbf{x})=\mathbf{w}^{\mathrm{T}} \phi\left(\mathbf{x}^{n}\right)-\rho
$$

ここで， $\mathbf{w}$ は重みベクトル $\phi(\cdot)$ は，入力空間から特徵 空間への写像をあらわ寸. 異常検知の境界 $f(\mathbf{x})=0$ と 原点との距離である margin は， $\rho /\|\mathbf{w}\|$ であらわされる。 したがって，\|w\|を大きくし， $\rho$ を小さくすれば margin は大きくなる.したがって，OCSVMの主問題は，

$$
\min _{w, \rho \in R} \frac{1}{2}\|w\|^{2}-\rho+\frac{1}{n v} \sum_{i \in[n]} \max \left\{0,-\left(\mathbf{w}^{T} \phi\left(\mathbf{x}^{n}\right)-\rho\right)\right\}
$$

と定義される．ここで，第一項，二項は，margin を大き くするための項である. 第 3 項は，SVM におけるヒン ジ損失関数に該当する．学習データのうちパラメータ $v \in(0,1]$ の割合のデータが，原点側（外れ值側）に残る. 式(I.3)は，最小化，最大化項が混在し，複雑な最適化問 題となっている. よって, 簡単のために, 式(I.3)の双対 問題を考える. 式 (I.1) のカーネル関数 $K\left(\mathbf{x}^{n}, \mathbf{x}_{i}^{n}\right)$ を導 入すると，双対問題は，下式で定義される.

$$
\begin{aligned}
\min _{\alpha \in R^{n}} & \frac{1}{2} \sum_{i \in[n]} \sum_{j \in[n]} \alpha_{i} \alpha_{j} K\left(x_{i}, x_{j}\right), \\
\text { s.t. } & 0 \leq \alpha_{i} \leq \frac{1}{n v}, \forall i \in[n], \\
& \sum_{i \in[n]} \alpha_{i}=1 .
\end{aligned}
$$

と定義される. ここで， $\alpha_{i}$ は双対変数，vは，八イパー パラメータである. OCSVM は， $\gamma, v$ が与えられた下で, 式(I.4a)を解けば，識別関数 $f(\mathbf{x})$ が一意に決定する. 本 研究では, 災害時のデータ $x_{i}^{d}$ を識別関数 $f(\mathbf{x})$ に入力し, 
$f\left(x_{i}^{d}\right)<0$ であれば迂回として検出する.

\section{付録 II OCSVMのパラメータ推定法}

パラメータ $\gamma, v$ の推定法を述べる. $\gamma$ は，既往研究に 基づき, グラム行列（全サンプルでカーネル関数を計算 した行列）の分散が最大となるように推定した。 vはグ リッドサーチで推定した. グリッドサーチとは，予め列 挙したパラメータの全組み合わせをモデルに入力し，最 もよいパラメータの組み合わせを推定值とする手法であ る. 本研究で検出する迂回（異常）は，“平常時に選択 されない迁回路（平常時に見られないデータ）”である. したがって，この迂回の条件を満たすように，グリッド サーチにより，平常時のデータを全て “正常（迂回では ない)”と判定し，かつ $v$ が最大となる值を探索し，推 定值とした．上記のパラメータ推定方法は，過去の文献 でも記載されている．詳細は，参考文献 2),3)もしくは， その他 OCSVMに関する研究論文を参照されたい.

\section{参考文献}

1) 富士通交通・道路データサービス HP， http://www.fujitsu.com/jp/group/ftrd/

2) Scholkopf, B., Platt, J., Shawe-Taylor, J., Smola, A. and Williamson, R. : Estimating the support of a highdimensional distribution, Neural Computation, Vol. 13, Issue 7, pp. 1443-1472, 2001.

3) 井出剛, 杉山将: 異常検知と変化検知（機械学習プ ロフェッショナルシリーズ），講談社，2015.

4) 日下部貴彦, 社領沢, 朝倉康夫 : 都市高速道路にお ける突発事象時の行動調査とその分析, 土木学会論 文集 D3 (土木計画学), Vol. 68, No. 5, pp. I_731-I_740, 2012.

5) Wardman, M., Bonsall, P. W. and Shires, J. D. : Driver response to variable message signs: a stated preference investigation, Transportation Research Part C, Vol. 5, pp. 389-405, 1997.

6) Peeta, S., Ramos, J. L. and Pasupathy, R. : Content of variable message signs and on-line driver behavior, Transportation Research Record, No. 1725, pp. 102-108, 2000.

7) 森井健介, 宇野伸宏, 中村俊之, 織田利彦, 倉内文 孝, 清水明彦：SP 調査による豪雨情報提供時の経路 選択行動に関する基礎的研究，土木学会論文集 D3 (土木計画学), Vol. 72, No. 5, pp. I_1187-I_1197, 2016.

8) 朝倉康夫, 柏谷増男, 高木一浩, 藤原健一郎：災害 による道路通行規制時の交通選択行動に関する実証 分析, 土木計画学研究・論文集, No. 14, pp.371-380, 1997.

9) 藤田素弘，三田村純：東海集中豪雨下における自動 車帰宅交通状況と走行経路解析, 土木学会論文集, No. 751/IV-62, pp. 127-137, 2004.

10) Bengtsson, L., Lu, X., Thorson, A., Garfield, R. and von Schreeb, J. : Improved response to disasters and outbreaks by tracking population movements with mobile phone network data: a post-earthquake geospatial study in Haiti, PLoS Med., Vol. 8, No. 8, p. e1001083, 2011.

11) Lu, X., Bengtsson, L. and Holme, P. : Predictability of population displacement after the 2010 Haiti earthquake, Proc. Natl. Acad. Sci. USA, Vol. 109, No. 29, pp. 1157611581, 2012.

12) Hara, Y. and Kuwahara, M. : Traffic monitoring immediately after a major natural disaster as revealed by probe data - A case in Ishinomaki after the Great East Japan Earthquake, Transportation Research Part A : Policy and Practice, Vol. 75, pp. 1-15, 2015.

13) Kawasaki, Y., Kuwahara, M., Hara, Y., Mitani, T., Takenouchi, A., Iryo, T. and Urata, J. : Investigation of traffic and evacuation aspects at Kumamoto earthquake and the future issues, Journal of Disaster Research, Vol. 12, No. 2, pp. 272-286, 2017.

14）関塚貴一, 三谷卓摩, 川崎洋輔, 益田卓朗, 永井慎 一，桑原雅夫：車両軌跡のみを用いた突発事象発生 時の旅行時間予測, 土木計画学研究・講演集, Vol. 53, CD-ROM, 2016.

15) Asakura, Y., Kusakabe, T., Nguyen, L. X. and Ushiki, T. : Incident detection methods using probe vehicles with onboard GPS equipment, Transportation Research Part $C$ : Emerging Technologies, Vol. 81, pp. 330-341, 2017.

16) Cai, Y., Wang, H., Chen, X. and Jiang, H. : Trajectorybased anomalous behaviour detection for intelligent traffic surveillance, IET Intelligent Transport Systems, Vol. 9, pp. 810-816, 2015.

17) 日下部貴彦：全国規模のプローブカーデータを用い た広域的異常事象の検出手法の構築, 土木計画学研 究・講演集, Vol. 55, CD-ROM, 2017.

18) Yoshida, M., Umeda, S., Kawasaki, Y. and Kuwahara, M. : Incident alert by an anomaly indicator of probe trajectories, Transportation Research Procedia, Vol. 34, pp. 179-186, 2018.

19) Umeda, S., Kawasaki, Y. and Kuwahara, M. : Analysis of traffic state at heavy rain disaster using probe data, Journal of Disaster Research, Vol. 14, No. 3, pp. 466-477, 2019.

20) 愛媛県庁 HP, https://www.pref.ehime.jp/h12200/ documents/higai100.pdf（2019 年 2 月 18 日アクセス）

21）小野田崇: One-Class SVM に基づく水力発電所におけ るリスクマネジメント, Operations Research as a Management Science Research, Vol. 51, No. 11, pp. 683-688, 2006.

22）豊嶋伊知郎, 服部可奈子, 板倉豊和, 榎原孝明, 馬 場賢二，折原良平：クラスタリング結果を用いた外 れ值検出による, 歩行軌跡データからの行動識別手 法, IPSJ SIG Technical Reports, Vol. 31, pp. 205-212, 2007.

23) 杉山将, 井手剛, 神嶌敏弘, 栗田多喜夫, 前田英 作 : 統計的学習の基礎一データマイニング・推論・ 予測一，共立出版， 2014.

24) 杉山将：密度比に基づく機械学習の新たなアプロー 于, 統計数理, Vol. 58, No. 2, pp. 141-155, 2010.

25) Han, J., Kamber, M. and Pei, J.: Data Mining - Concepts and Techniques, Third Edition, Morgan Kaufmann, 2011.

(Received February 27, 2019) (Accepted August 27, 2019) 


\title{
DETECTION AND ANALYSIS OF DETOURS OF COMMERCIAL VEHICLES DURING HEAVY RAIN IN WESTERN JAPAN USING MACHINE LEARNING TECHNOLOGY
}

\author{
Yosuke KAWASAKI, Shogo UMEDA and Masao KUWAHARA
}

In this study, we detect detours of commercial vehicles during heavy rain in western Japan using machine learning technology, and analyze the cause of the detours. During the heavy rain of 2018 in western Japan, road regulation caused by this rain occurred over a wide area. There is probe trajectories generated by GPS which reveals the detour route taken. The necessity of taking the detour is one of the traffic failures caused by disasters. However, in order to reveal the detour, it is necessary for the road administrator to visually check and analyze the probe vehicle trajectory, which requires a lot of labor. So, in this study, we tried to detect detours during disasters by learning the probe vehicle trajectory under normal circumstances using a One-class support vector machine (OCSVM). As a result of detecting detours for Shikoku, even if the nearest detour route was accessible, we identified vehicles using more distant detour routes. As a result of analyzing the cause of the detour, it was suggested that the "risk" of the traffic failure is one factor. 